\title{
An Assessment of Ecotourism Potentials in Kupe Muanenguba Division, South West Region, Cameroon
}

\author{
Balgah Sounders N. (PhD)*1, Nfor Frederick*2 \\ ${ }^{* 1}$ Associate Professor of Geography, Department of Geography, Faculty of Social and Management Sciences, University of \\ Buea-PO Box 63 Buea, Cameroon. \\ *2Nfor Frederick, Department of Geography, Faculty of Social and Management Sciences University of Buea-PO Box 63 \\ Buea, Cameroon.
}

\begin{abstract}
Kupe Muanenguba Division (KMD) can be termed as an ecotourism cornucopia because of her richness in floral and faunal biodiversity, juxtaposed with beautiful terrain and lakes as well as a wonderful cultural mix. The main objective of this study was to identify and assess the ecotourism potentials in the division so as to create awareness to nationals and foreign tourists on what this division is endowed with. Data for this study consisted of primary and secondary sources. Primary sources of data collection included on-the-spot observation, interviews and the use of camera. The Geographic Positioning System (GPS) was also used to map out the ecotourism potentials and tourism infrastructures in KMD. Secondary sources of data collected included literature from published and unpublished sources such as: text books, articles, journals, reports of research organizations and theses. Stratified and purposive sampling techniques were used in the administration of the questionnaires. Results revealed that KMD is endowed with rich ecotourism potentials that are still lying unharnessed meanwhile others are not even known to all and sundry. The study has recommended amongst others that the Cameroon government should involve the indigenous people (by employing them and taking their own opinions into account) in the protection and conservation of the natural resources and involve them in all ecotourism activities.
\end{abstract}

Keywords- Ecotourism, ecotourism potentials, Muanenguba Twin Lakes, challenges of ecotourism, Kupe Muanenguba Division.

Acronyms-BMWS: Banyang Mbo Wildlife Sanctuary, GPS: Global Positioning System, IUCN: International Union for the Conservation of Nature, IYE: International Year of Ecotourism, KMD: Kupe Muanenguba Division, MINTOUR: Ministry of Tourism and Leisure, MKF: Mount Kupe Forest, MMF: Muanenguba Mountain
Forest, UNWTO: United Nations World Tourism Organization

\section{INTRODUCTION}

Ecotourism has become a popular global leisure activity, around the world today, ecotourism has been hailed as a panacea; a way to find conservation and scientific research, protect fragile and pristine ecosystem, benefit rural communities, promote development in poor countries, enhance ecological and cultural sensitivity, instill environmental awareness and social conscience in the travel industry, satisfy and educate the discriminating tourists and some claim, build world peace (Honey, 2008).

The significance of ecotourism potentials in environmental and cultural preservation have been recognized internationally through the International Year of Ecotourism (IYE) [2002], the Johannesburg Summit on Sustainable Development (2002) and a number of related international processes and events. Ecotourism remains a key area of the work of the UNWTO and it is also one of the priorities in its Special Programs for Sub-Saharan Africa.

Cameroon has long been a touristic destination since from the time of the Carthaginians who spotted 'The Chariots of the gods'. This fire-spitting mountain now known as the Mount Cameroon was the country's first best-selling tourist attraction and it is still a marveling structure right up to the present date (Chombeng, 2015). But it was not until a few decades ago that tourism in Cameroon started seeing the light of day despite its spectacularly beauty panoramas, scenic splendors and magnificent views and unique wild life (Ndenecho, 2005). Cameroon is generally regarded as a microcosm of Africa-hence the name 'Africa in Miniature' as it cuts through all major climatic and ecological zones of the African continent, and also standing at the cross-roads of most cultures, it is 
a cultural melting pot (Lambi, 2010; Mesmin and Fogwe, 2009; Benneth, 2008 and Neba, 1987). Cameroon in 2010, received 572,728 visitors thereby making it a touristic destination according to the UNWTO standards (MINTOUR, 2012).

Kupe Muanenguba Division (KMD) in the South West Region of Cameroon is second only to Fako in terms of ecotourism potentials. In KMD, many of these ecotourism sites include the famous Muanenguba Twin Lakes, the Ndebsi Hot Spring, the Lake Bermin, just to name but these, together with their numerous cultural artifacts and cultural manifestations will be highlighted and brought to the limelight in this article for better appreciation to all and sundry.
II.

\section{THE STUDY AREA AND THE PROBLEM BACKGROUND}

Kupe Muanenguba Division (KMD) is located between longitudes $9^{0} 9^{1} \mathrm{E}$ and $9^{0} 48^{1} \mathrm{E}$ and latitudes $5^{0} 33^{1} \mathrm{~N}$ and $4^{0} 41^{1} \mathrm{~N}$ of the equator. This Division was created in 1993 comprising three Sub-divisions, that is, Bangem, Nguti and Tombel Subdivisions with its headquarter in Bangem (Map 1.1). KMD has a total surface area of $3,951 \mathrm{~km}^{2}$ with 189 villages. The fringe location of this division poses access constraints to the various ecotourism sites but gives room to nature-based relatively undisturbed sites and cultural based potentials which are key assets for ecotourism development.

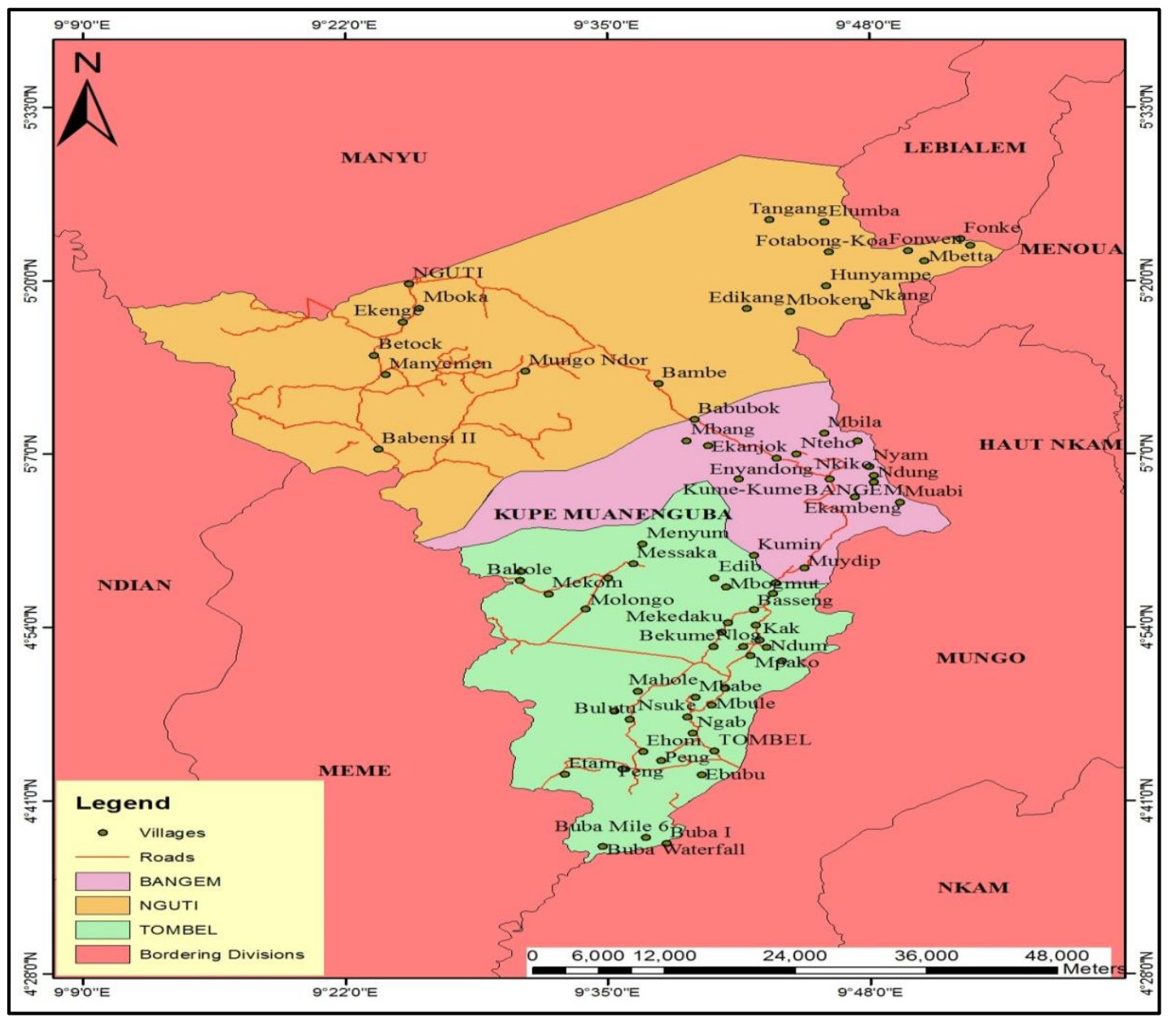

Map.1: Layout of Kupe Muanenguba Division

The climate of KMD is dominated principally by the Equatorial Guinean type of climate, characterized by the rainy and dry seasons. Temperature averages between $20^{\circ} \mathrm{C}$ and $28^{\circ} \mathrm{C}$ but sometimes it reduces to about $15^{\circ} \mathrm{C}$ to $17^{\circ} \mathrm{C}$ on Mt. Kupe, Mt. Muanenguba and on the caldera due to the influence of altitude. The average humidity in this division averages about 75\%-80\% (Zangmo et al., 2007 in Diabe, 2010). All these weather characteristics are conducive for ecotourism exploration especially for tourists from Europe and North America.
The forest in Bangem is unique. This uniqueness stems from the fact that this forest is a transition from the equatorial rainforest at its borders, to the sub-montane and montane forest, shrubs and grassland. It has one of the best-developed sub-montane forests in West Africa and it is rich in montane endemic species (Melle, 2009). These forests are home for bird species like the Mount Kupe Bush Shrikes which are very attractive to tourists especially during bird watching. 
Kupe Muanenguba Division, just like other divisions of the South West Region of Cameroon has witnessed an increase in its population since 1976. In 1987, KMD has a population of 82,952 inhabitants. With a total surface area of $3,404 \mathrm{~km}^{2}$, this gave a population density of 24.37per $/ \mathrm{km}^{2}$ (Annuaire Statistique du Cameroun, 2000). Following the 2005 National Census Results of Cameroon, the population of KMD increased to 105,579 with a population density of $31.0 \mathrm{per} / \mathrm{km}^{2}$ and it was projected to be 117,321 in 2010 with a population density of $34.5 \mathrm{per} / \mathrm{km}^{2}$ (Annuaire Statistique du Cameroun, 2010).

\section{STATEMENT OF THE PROBLEM}

Kupe Muanenguba Division is richly endowed with ecotourism potentials with much reminiscent of the Mountain National Park in Asheville (United States), Sinharaja Forest in Sri Lanka, Viroinval Nature Park in Belgium and Jos Plateau Wildlife in Nigeria (Falade, 2000). If these potentials found in KMD are not well valorized and appraised, they cannot provoke substantial commitment and investment by the private and public sector actors of the tourism industry. The various ecotourism sites can be exploited for ecotourism development as has been the case with other ecotourism sites in the Region (like that in Fako Division) to provide employment and encourage environmental conservation and sustainability. Unfortunately, many of these potentials in KMD particularly the Muanenguba Twin Lakes, Lake Bermin and the Ndebsi Hot Spring amongst others, are lying idle while others are not even known by some of the locals and Cameroonians at large as ecotourism potentials, resources or assets.

Kupe Muanenguba can rightly be described as 'a Division found in the sea yet dying because of thirst' (the paradox of plenty). This is because this Division is endowed with enormous tourism potentials, yet these seem to have created little socio-economic impacts on the community. For example, many youths are still jobless and very limited income is being generated from the tourism industry. Many tourists visit these areas but little amount of money is paid to the local community. More so, if the tourists are 'Blacks' or nationals most of them do not even pay because the guards consider these black tourists as nationals, meanwhile, some may not be. In Bangem, the headquarters of $\mathrm{KMD}$, there is no operational Divisional Delegation for Tourism and Leisure. All these are aspects that go to show that the industry is poorly regulated; hence the exploitation of the local residents has become evident.

The absence of good modern and standardized hotels in KMD, characterized by air conditioners and wireless internet as well as swimming pools to give the tourists all the comfort they need poses a problem. This problem of limited and poor accommodation facilities make the duration of stay of tourists in the division to be shortlived. This of course, restricts the inhabitants of the Division to fully enjoy the benefits that accrue when tourists stay longer in tourism destination. It is against this backdrop that this article investigates the potentials and challenges of ecotourism in KMD.

\section{MATERIALS AND METHODS}

Data for this research was obtained through primary and secondary sources. Primary sources of data included personal interviews, field observation (primary data procedure), the use of camera, thermometer, Geographic Positioning Systems (GPS), questionnaires and the use of Focus Group Discussions (FGDs).

Secondary sources included materials from published and unpublished works related to the current study, maps and the exploitation of aerial photographs. Also, other secondary sources included office registers, statistics and figures, research reports, seminar reports, reports from international organizations.

Data acquired was analyzed by using both qualitative and quantitative statistics while graphs, tables, pie charts and bar graphs were used to represent data where necessary.

\section{PRESENTATION OF RESULTS AND DISCUSSION}

The section embodies results of field investigations analyzed under the following sub headings:

5.1. Ecotourism potentials (natural potentials) in KMD

Tourism assets are essentially the main factors that encourage and motivate tourists in choosing a particular destination. That is why any country that is considering the development of its tourism sector should carefully calculate its tourism related assets and resources. KMD is endowed with multifarious natural attractions which if judiciously or efficiently harnessed would make the tourism sector in this division a lucrative one. The division (as illustrated on Map 2) is endowed with a handful of physical, human and cultural ecotourism potentials as well as a few hotels to accommodate tourists. 


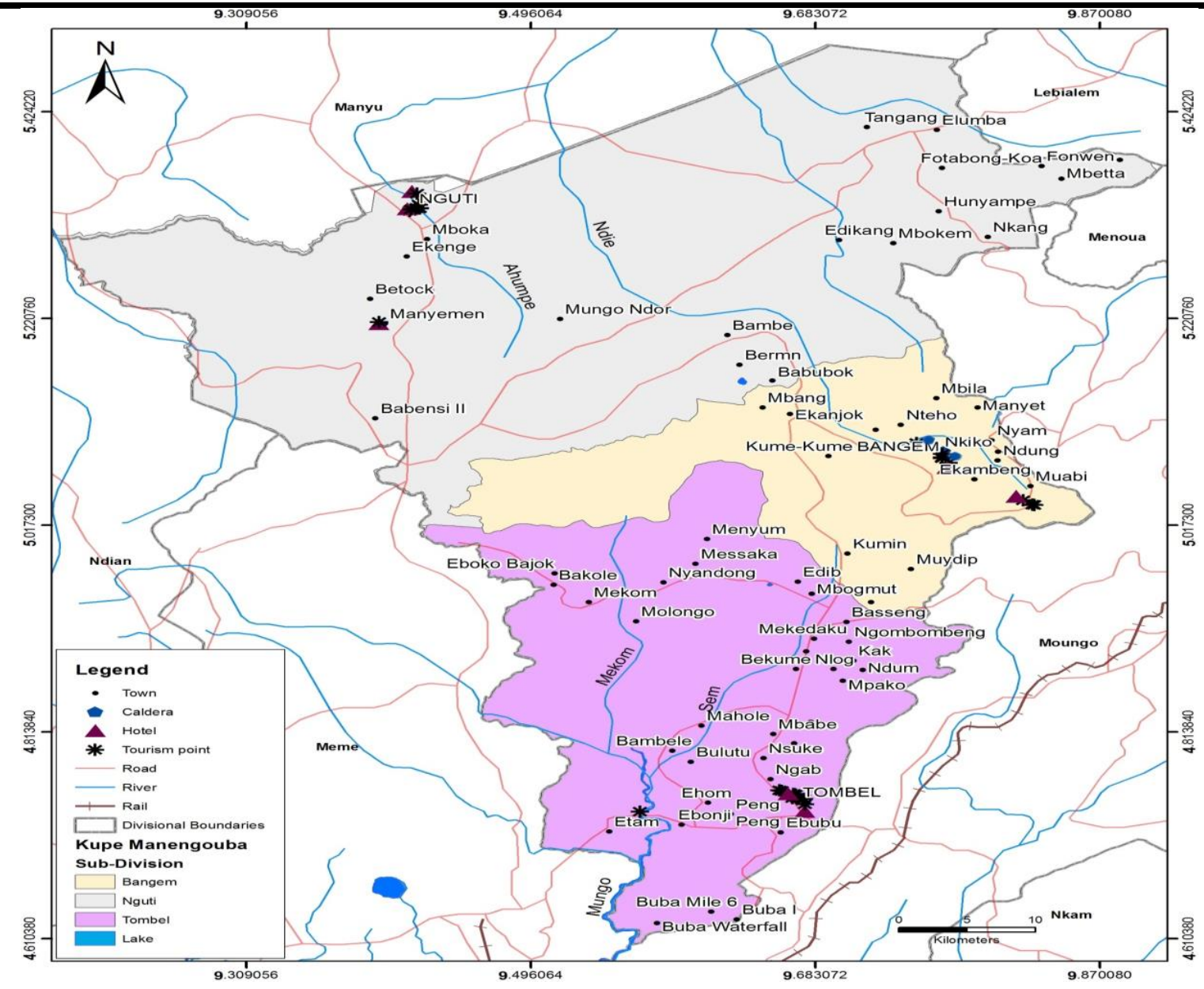

Map.2: Ecotourism Potentials and Tourism Infrastructures in KMD Physical / Natural Ecotourism Potentials

\subsection{1a . Lakes}

There are three main lakes found in KMD; the Muanenguba Twin Lakes and the Lake Bermin.

\subsection{1a(i) Muanenguba Twin Lakes}

This is the most prominent touristic site in KMD and even within the entire Region because of its uniqueness. These crater lakes are found on the Muanenguba Caldera. Two of the lakes contain water (crater lakes) and the third crater collects water seasonally (during the rainy season) and dries out during the dry season thus it is commonly called 'The Child Lake'. The 'Male Lake' as it is called, is located at latitude $5^{0} 02^{\prime} \mathrm{N}$ and longitude $9^{0} 50$ ' $\mathrm{E}$. It is found on an altitude of $1,900 \mathrm{~m}$ above sea level covering a surface area of $8,400 \mathrm{~m}^{2}$ with a depth of $92 \mathrm{~m}$ (Ndenecho 2005, Ndenecho \& Fonteh , 2012). This Lake looks greenish and frightful (Plate1A ) and also has some distinct characteristics (Table 1).
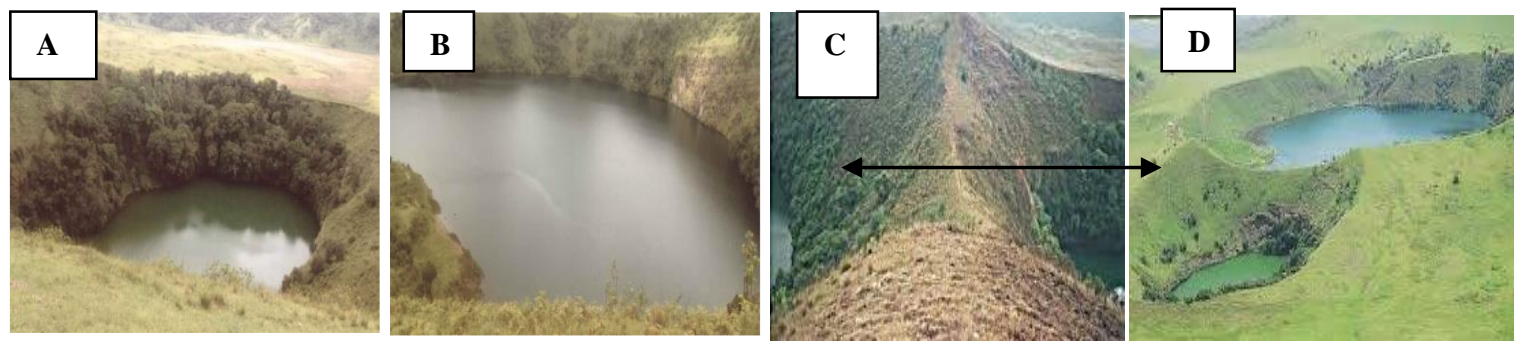

Plate.1: The Muanenguba Twin Lakes (A and B) and its Surrounding Features $(C \& D)$

The other lake called the 'Female Lake' is located at latitude $5^{\circ} 02^{\prime} \mathrm{N}$ and longitude $9^{0} 50$ ' $\mathrm{E}$, is bigger in surface area $\left(176,400 \mathrm{~m}^{2}\right)$ with steep slopes of about $50^{0}$ that rises to an altitude of 1,920m (Ayonghe \& Titangi 2000). This lake is friendly from its appearance, hence is drinkable and swimmable (Plate 1B). This 'Female Lake' has a depth of about $63.50 \mathrm{~m}$ and a diameter of $300-500 \mathrm{~m}$ (Diabe 2010). The exposure of the 'Female Lake' to the 
sun rays gives it a sparkling color and a glittering outlook which is attractive to tourists. The attractiveness of this lake is further buttressed by the scenic splendor that surrounds the lake including the famous buckaroos built at the banks of the 'Female Lake' to relate nature and the culture of the Bakossi people.

Table.1: Some Distinctive Characteristics of the Muanenguba Twin Lakes and the Lake Bermin

\begin{tabular}{|l|l|l|l|}
\hline \multicolumn{1}{|c|}{ Characteristics } & \multicolumn{1}{|c|}{ 'Male' Lake } & \multicolumn{1}{c|}{ 'Female' Lake } & \multicolumn{1}{c|}{ Bermin } \\
\hline Size & Small & Large & Small \\
\hline Color & Greenish & Bluish & Bluish \\
\hline Depth & Deeper (92m) & Deep (63.5m) & $?$ \\
\hline Swimming status & Forbidden & Not forbidden & Not forbidden \\
\hline Potability & Not potable & Potable & Potable \\
\hline Appearance & Frightful & Friendly & Friendly \\
\hline Accessibility & $\begin{array}{l}\text { Difficult due to its steep } \\
\text { sides }\end{array}$ & Accessible & Accessible \\
\hline $\begin{array}{l}\text { Cultural heritage } \\
\text { status }\end{array}$ & $\begin{array}{l}\text { It is believed to harbor } \\
\text { ancestors }\end{array}$ & $\begin{array}{l}\text { It is believed not to } \\
\text { harbor ancestors }\end{array}$ & $\begin{array}{l}\text { It is believed to have } \\
\text { some mysterious } \\
\text { power }\end{array}$ \\
\hline
\end{tabular}

Between the 'Male' and the 'Female' Lakes, there is an interesting feature, a ridge separating the lakes, as illustrated with an arrow on Plate $1 C$ \& D. It is believed by the natives that at night, water in the 'Male' Lake flows into the 'Female' Lake, indicating constant communication between the lakes.

\subsection{1a(ii) Lake Bermin}

Lake Bermin is a small lake in the volcanic chain, found in Bermin Village, Nguti Sub-division. It is a volcanic lake with a crater rim that rises to a height of about $150 \mathrm{~m}$. This highly isolated lake is roughly circular in shape, lacks inflow but has an outflow to the cross river system. Despite its small size (Plate 2A); it supports 9 endemic species of tilapia fishes. This number of endemic fishes per area is the highest recorded elsewhere within the Subdivision (Diabe, 2010). Note that these aquatic animals are critically endangered by pollution and sedimentation from human activities. This lake attracts tourists though the number is limited because of accessibility constraints to the area. It is worth mentioning that the characteristics of the 'Female' Lake are similar to those of Lake Bermin (Table 1).


Plate.2: Lake Bermin (A), Ndebsi Hot Spring (B) and River Mbwe (C)

\subsection{1b. Hot Spring at Ndebsi}

There is a hot spring at Ndebsi, some $3 \mathrm{~km}$ from the central town of Bangem. Field investigation (2016) revealed that this spring (Plate $2 \mathrm{~B}$ ) has a temperature of $42^{\circ} \mathrm{C}$ while River Mbwe (Plate $2 \mathrm{C}$ ) which is very near has a lower temperature of $34^{\circ} \mathrm{C}$. Interestingly, the Ndebsi hot spring is about $5 \mathrm{~m}$ away from River Mbwe with two distinct temperatures.

The inhabitants believe that this spring has some medicinal values which is helpful in the treatment of skin diseases like eczema and ringworm. Initially, it was bubbling at a height of $1 \mathrm{~m}$ but today due to deforestation and the transformation of the surrounding into a cultural landscape, the height has dropped to about $0.7 \mathrm{~m}$. It was realized that most indigenes of Ndebsi farm around this area with the motive that whenever the area is to be harnessed by the government as a touristic site, the farmers around the hot spring will be compensated. What is amazing in this area is that the surface soil is always warm even in the heart of the rainy season. This touristic asset pulls tourists from some parts of the world, notably from France for research purposes. It is common to see tourists returning from this area with samples of water from the hot spring. Geologists and volcanologists also visit the area to be able to predict when the next eruption 
may occur. This has therefore made this spring to become one of the major research sites in this division.

\subsection{1c. Kupe and Muanenguba Mountains}

Mounts Kupe and Muanenguba (from which the division got it name) are a chain of mountains located in the South West and Littoral Regions of Cameroon. They have a volcanic origin and cover the eastern part of Bangem Subdivision, stretching right up to Mungo Division in the Littoral Region. Mount Kupe is 2,050m and Mount Muanenguba has a height of approximately 2,396m with a diameter of about $25 \mathrm{Km}$. It falls along the Cameroon Volcanic Line (CVL) punctuated with rocky hills and plateaux.

These mountains are said to carry some of the oldest forests in Africa (Mesumbe, 2001). With these altitudes the mountains serve as an important water reservoir for most of the South-Western areas of Cameroon and the home to some rare bird species like the Mount Kupe Bush Shrike (Malaconotus kupeeris) and plant species like African tropicana. When some of these tourists get to the foot of the mountain, they decide to trek in order to enjoy the wonderful splendor and magnificent beauty of the undulating terrain covered by grasses and patches of the forests.

\subsection{1d.Vegetal/wildlife resources and protected areas}

Vegetal resources include the Mount Kupe Forest while protected areas include the Bakossi Forest Reserve / Bakossi National Park and the Banyang Mbo Forest Reserve (Banyang Mbo Wildlife Sanctuary).

\subsection{1d (i) Mount Kupe Forest (MKF)}

This is another ecotourism potential that has attracted many national and foreign ecotourists. The MKF is famous for its large number of birds, animals, frogs and a host of medicinal plants. Over 329 species of birds have been recorded on this mountain amongst which are: Mount Kupe Bush Shrike (Malaconotus kupeenis), White-Throated Babbler (Kupeornis gilberti), GreenBreasted Bush Shrike (Malaconotus gladiator), and GreyNecked Picathartes (Picathartes oreas) (Ndenecho, 2005).

This forest is also home to primate species including the highly endangered drill (Mandrillus leucophaeus), the less well-known relatives of mandrill, are one of the most endangered primate species in the world. They are found only in West Cameroon and Eastern Nigeria and the Mount Kupe Forests are home to some healthiest population of these drills still remaining in the wild. Some of the mammals also found in this MKF include: Preuss Monkey (Ceropithecus preussi), Red-Eared Monkey (Ceropithecus erythrotis), Putty Nose Guenon (Ceropithecus nictitanus) and several species of Bush Baby, Red Capped Mangabey (Cerocebus torquatus),
Chimpanzee and the Preuss' Red Colobus (Piliocolobus preussi) (IUCN, 2007). In this montane forest, there also exist antelopes, elephants and buffalos that roam parts of the 'Black Bush' as the locals call the dense forest.

The endemic amphibian species (like frogs) are known to be regularly hunted from the forest for domestic food and they require forest vegetation and riparian microhabitats to survive. Although these species have a wide distribution, they are certainly declining as the natives reside in the face of expanding agriculture. It is worth noting that about $25 \%$ of amphibians in this montane forest are considered threatened with deforestation being the main cause. All the above characteristics of the montane forest make it a great biodiversity milieu for both fauna and flora, hence acting as a citadel for many national and foreign ecotourists.

\subsection{1d (ii) Muanenguba Montane Forest (MMF)}

The MMF is found on Mt. Muanenguba in Bangem Subdivision and it inhabits part of the Bakossi National Park (Ejedepang, 1986). It equally constitutes the Muanenguba Integral Ecological Reserve (MIER). The MMF is in the humid tropics, which has tropical rainforest vegetation, but the altitudinal variation has given rise to dominant grassland vegetation and some patches of forest in the Twin Lake areas. The region has a transition from equatorial rainforest at its borders, to sub montane and montane forest, shrubs and grasslands. It has one of the best developed sub montane forest in West Africa and it is rich in montane endemics of Guinea Congolian affinity (Ndenecho, 2005).

This forest plays host to a variety of flora and fauna species with a plethora of bird species such as the whitethroated babbler and the grey-necked picathartes and a host of reptiles. The tree species here are of medicinal significance and are always used by traditional practitioners in this locality for treatment purposes. The MMF is dense on the southern slopes and has a lot to offer as far as ecotourism is concerned. It should be noted that MMF has similar characteristics in the nature of their natural endowment of flora and fauna species as the MKF hence; it accommodates a variety of endemic species of flora, fauna, birds and amphibians as well as reptiles. This area being a panorama of montane endemics still harbors some species of plants, animals, birds, reptiles and amphibians which are extinct in other parts of the world (Ndenecho, 2005). No doubt it is a tourist destination.

The flora species in the MMF vary with altitude (Mesumbe, 2001; Fotso \& Ewane, 2001). This is why there are upper mountain species as well as lower mountain species. This variation is primarily due to temperature variation with altitude. It should be noted that these upper montane species are highly medicinal and some of them are used in the production of modern 
medicine and for traditional healing practices. Table 2 illustrates some of the upper montane flora species and their scientific family names. Tourists visit this montane

Table.2: The Upper Montane Tree Species and Family.

\begin{tabular}{|l|l|l|}
\hline English Name & Scientific Name & Family Name \\
\hline Pandol & Ericaulon par valum & Rebiaceae \\
\hline African copaiba tree & Daniellia oliveri & Fabaceae \\
\hline Sword lily & Gladiolus delenii & Iridaceae \\
\hline Wild seringa & Burkea africana & Fabaceae \\
\hline Ladies mantle & Alchemilla mollis & Rosasceae \\
\hline Poker plant & Kniphora reflexa & Asphodelaceae \\
\hline Devils coach whip & Starchytarpheta angustiolia & Verbanaceae \\
\hline
\end{tabular}

The Muanenguba highland is also rich in lower montane savanna species, some of which are unique in the Muanenguba highland area. These species are abundant and varied as seen on Table 3 and 4.

Table.3: The Lower Montane Savanna

\begin{tabular}{|l|l|l|}
\hline English Name & Scientific Name & Family Name \\
\hline Monkey bread & Piliostigma thonningii & Leguminosae \\
\hline African custard apple & Annona senegalensis & Annonaceae \\
\hline Bidi leaf tree & Pilliostigma racemosum & Fabacieae \\
\hline Red milk wood & Mimusops zeyheri & Granineae \\
\hline Drumstick tree & Moringa oleifera & Asclepiadaceae \\
\hline Velvet leaf & Combretum molle & Combritaceae \\
\hline Iron wood & Prosopis africana & Fabaceae \\
\hline South African grass & Setaria sphacelata & Combretaceae \\
\hline Bermuda grass & Cyanadon dactylon & Graninieae \\
\hline
\end{tabular}

\subsection{1d (iii)The Banyang Mbo Wildlife Sanctuary (BMWS)}

The BMWS was created in 1996 by Decree No. 96/119/PM of $12^{\text {th }}$ March 1996 and it has as geographical coordinates latitudes $5^{0} 30^{\prime} \mathrm{N}-5^{0} 34^{\prime} \mathrm{N}$ and longitudes $4^{0} \mathrm{E}$ $9^{0} 45^{\prime} \mathrm{E}$ and the elevation ranges from $120 \mathrm{~m}$ to $1,750 \mathrm{~m}$ (BMWS office Nguti, 2013). It has a surface area of 66,200 hectares and this protected area has specifically designated animals and plant species that are given full protection. Recent survey suggests that this $680 \mathrm{~km}^{2}$ BMWS provide habitat for possibly the largest number of chimpanzees remaining in the South West Region of
Cameroon and the last remaining sizeable population of elephants. Five hundred to one thousand NigerianCameroonian chimpanzees (Pan troglodytes ellioti) inhabit this sanctuary and there are only 3,500-9,000 remaining in the entire world (Ndenecho, 2011). Other animal types found in this sanctuary include: preuss's redcolobus, leopard (Panther pardus), Collared Mangabey (Cercocebus torquatus) and buffalo (Syncerus caffer), forest elephant, dwarf crocodile amongst others, with 207 plant species, 32 plant family, 325 bird species (BMWS office 2013, www.birdlife international.org, accessed March 2015).

Table.4: Some medicinal plants found in protected areas in KMD and their economic values

\begin{tabular}{|l|l|l|l|}
\hline \multicolumn{1}{|c|}{ Plant Species } & Life Form & \multicolumn{1}{c|}{ Plant Parts Used } & \multicolumn{1}{c|}{ Observation } \\
\hline Aframomum spp & Herb & Fruit, leaf, stem, seed & Sold in local and regional markets \\
\hline Alstonia boonei & Tree & Bark, latex, leave & Bark sold in local markets \\
\hline Annickia korupensis & Climber & Leaves & $\begin{array}{l}\text { Preliminary trials by scientists for the treatment of } \\
\text { AIDS and cancer }\end{array}$ \\
\hline Annickia chlorantha & Tree & Bark, leaves & Sold in local markets \\
\hline Baillonella toxisperma & Tree & Bark, seed oil & Sold in local markets \\
\hline Bryophyllum pinnatum & Herb & Leaves, fruits & Not sold in markets \\
\hline
\end{tabular}




\begin{tabular}{|l|l|l|l|}
\hline Canarium shwein furthii & Tree & Seed, fruits, resin bark & $\begin{array}{l}\text { Fruits sold in local markets, high value timber } \\
\left(40000 \mathrm{frs} / \mathrm{m}^{3}\right)\end{array}$ \\
\hline Ceiba pentanda & Tree & Leaves, bark, root & $\begin{array}{l}\text { Not sold in market } \\
\text { Timber sold }\left(8000 \mathrm{frs} / \mathrm{m}^{3}\right)\end{array}$ \\
\hline Cola spp. & Tree & $\begin{array}{l}\text { Seeds, leaves, bark, } \\
\text { roots }\end{array}$ & Sold locally and also exported to Nigeria \\
\hline Garcinia manni & Tree & Seeds, roots, bark latex & Seeds and barks sold on local markets \\
\hline Kigelia Africana & Tree & $\begin{array}{l}\text { Branches for chewing } \\
\text { sticks, leaves latex }\end{array}$ & $\begin{array}{l}\text { Bark is sold. There is significant trade in chewing } \\
\text { sticks }\end{array}$ \\
\hline Voacanga Africana & Tree & Seeds, latex, bark, roots & $\begin{array}{l}\text { Sold in world market. Fruits sold as spices. Barks } \\
\text { not marketed, sold to industries and some exported }\end{array}$ \\
\hline Spilanthes filicaulis & $\begin{array}{l}\text { Shrub } \\
\text { creeping }\end{array}$ & Leaves, barks, roots & Sold for industrial transformation \\
\hline Ricinodendron heudelotii & Tree & Leaves & Leaves sold as vegetable, stem and bark sold \\
\hline
\end{tabular}

Source: Adapted from Ndenecho (2011); Field Work (2016)

Endemic species of animals here include: the drill monkey and bird species endemic to Cameroon like the Mount Kupe Bush-Shrike and the Grey-Necked Picathartes. Some other birds found in this sanctuary include: Congo- serpant eagle, Afep pigeon, Yellow Spotted Barbet and White-Crested Hornbill.

It should be noted that all the animals, birds and plant species are a pull factor to many ecotourists and ecoresearchers. In order to facilitate the development of this sanctuary, the government signed a protocol agreement for 5 years with the Wildlife Conservation Society (WCS) on August 19, 1999 to assist in developing a community based management model for the sustainable management of the sanctuary.

\subsection{Cultural Ecotourism Potentials}

Kupe Muanenguba Division is endowed with a lot of cultural ecotourism potentials (tangible such as cultural artifacts and intangible such as cultural jamborees).
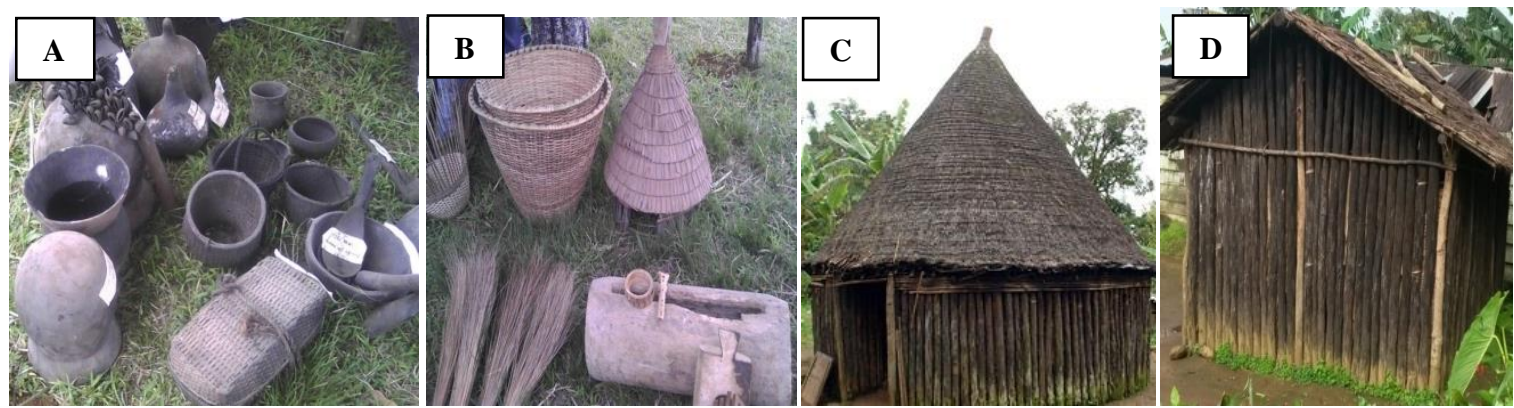

Plate.3: Cultural artifacts on display during cultural manifestations in Nkack village and Bakossi Traditional Houses; Ndab Echum $(C)$ and Ekulle (D)

Cultural jamborees and cultural artifacts are aspects that attract ecotourists and in which ecotourism seek to promote and develop. In terms of cultural manifestations, for example, during the general assembly of the Ninong Cultural and Development Association (NICDA), Nguti Cultural and Development Association (ELATIBEBUM) and All Bakossi Conference (ABC), the cultural manifestations of the people in this division are presented to the general public. These cultural manifestations are promoted (by tourists and guests) through encouragement of the dancers and presenters with gifts (financial and material). During such manifestations, cultural items (Plate 3. A \& B) with some that are more than a century old are displayed like, clay pots, calabashes and baskets as illustrated in Plate $3 \mathrm{~A}$.

Also, during cultural jamborees, what catches the attention of most tourists are the different dancing styles, dressing and the musical instruments used by the native population especially the Bakossi people. The most thrilling of these dances is the 'Ahon' society dance made up of people who have been initiated into the traditional cult. Other traditional dances that are practiced in KMD to the admiration of tourists are 'Ewa', 'Ngone'.and the 'Mal'. In addition, the designs of the traditional houses are also a great attraction to many tourists. These houses are built in a circular form (Plate 3C) or rectangular form (Plate 3D) with fern-trees and are roofed with thatches. These houses offer fascinating spectacles to tourists. It is constructed using raffia, cane and sticks (thatches). Because of the fact that many tourists do appreciate the indigenous nature of these houses, they have been constructed to function as Inns in the division, like the Prestige Inn in Bangem. 


\section{CHALLENGES OF ECOTOURISM DEVELOPMENT IN KUPE MUANENGUBA DIVISION}

Ecotourism in KMD is plagued by a myriad of problems that hinders its smooth functioning:

\subsection{Accessibility constraints}

The French Geographer, Vidal de la Blache stated that 'Les routes on fait les villes'. This means that 'where ever a road passes, development follows'. This is true in KMD because, poor road network in this area has hindered the development of ecotourism. Poor road network is a major challenge hindering the smooth functioning of the ecotourism sector in KMD. The roads to and within the various municipalities in the division are in a deplorable state. These roads are seasonal, characterized by being

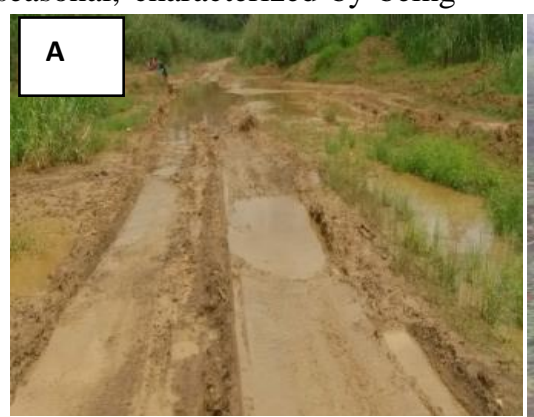

Plate.4: Nature of Roads in KMD

Moreover, the roads leading to the various touristic sites within the division are also in a bad state. For instance, the roads to Lake Bermin and the Muanenguba Twin Lakes have been neglected with the surface road washed away by gully erosion as can be seen on Plate 4B, typical of the road leading to the Twin Lakes. All these act as slippery and muddy during the rainy seasons, like the road linking Kumba and Tombel as illustrated on Plate $4 \mathrm{~A}$, and too dusty during the dry season. Some of the touristic sites are still enclaved and cut off from access to tourists who patronize the area. Hence, some of the ecotourism potentials (like Bambe Escarpment and Bake Waterfall) lie idle and unexploited.

It is worth mentioning that accessibility constraints discourages tourists from visiting KMD. These accessibility constraints have a negative influence on tourists' arrivals and earnings. This accounts for the low rate of tourism arrivals during the rainy season when accessibility is very poor and high during the dry season when the roads are dry. But during the dry season, too much dust is a deterrent to tourism activities.



$M D$ during the Rainy Season

hindrance to the free movement of tourists hence limiting tourists to the division only during the dry season. Field investigations revealed that $100 \%$ of the respondents in each of the Sub-divisions in KMD attested to the fact that there exist accessibility constraints and other challenges in KMD as illustrated on Figure 1.

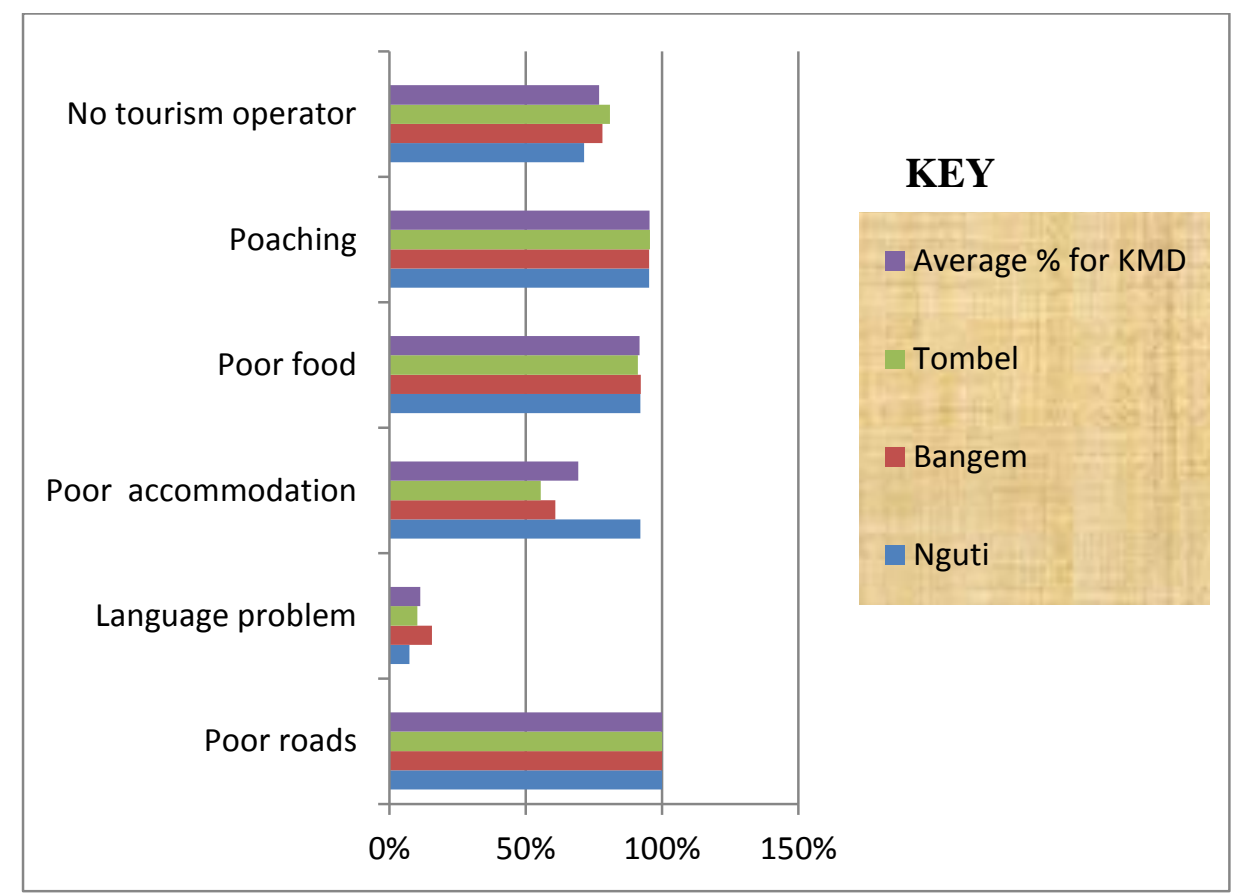

Fig.1: Challenges of Ecotourism in KMD as revealed by the respondents 
In a nutshell, a synopsis of the challenges plaguing ecotourism development in KMD include poor roads, poaching, poor accommodation, no tourism operators forest resource degradation amongst others as can been seen in Figure 1.

6.2 Limitations in Public and Private Sector Investments in Infrastructural Development

Findings revealed that poor accommodation is one of the major challenges of the tourism sector in KMD. Findings revealed that $92.1 \%$ of respondents in Nguti, $60.9 \%$ (Bangem), 55.9\% (Tombel) (as illustrated on Figure 1) and an average of $69.3 \%$ of the population of the KMD (Figure 1) attested to the fact that the accommodation facilities in KMD are inadequate. The few accommodation facilities available are below national and international standards. Only the Prestige Inn in Bangem with large and spacious rooms, constant flow of water in the baths, parking lots and other facilities make it closer to a modern hotel, though it lacks wireless internet connection and other facilities that can make a tourist more comfortable.



Fig.2: Sign Post of Green Castel Inn in Nguti, Notice the Quality of the Board and the Poor Spelling of the Word 'Castle'

From Figure 2, the poor nature of the sign post coupled with the fact that 'Castle' is wrongly spelt speaks for itself the nature of the hotel it is depicting. The rooms are dirty characterized by very narrow toilets with many of them having taps with no water running in them. Typical of this is the Green 'Castel' in Nguti, Victoria Island in Tombel and Farmer's Inn in Bangem. Worst still, none of the hotels are represented online, so it makes it difficult for tourists to make online booking / hotel reservation, in any of the hotels in KMD. In fact, the absence of modern accommodation facilities is one of the major challenges of ecotourism in KMD.

\subsection{The Political Will for Ecotourism Development in} KMD

Kupe Muanenguba Division is one of the unfortunate Divisions in the South West Region of Cameroon that has no Divisional Delegation of Tourism and Leisure (DDMINTOUR) as in Fako and in Manyu despite the much talked about decentralization in Cameroon. During an interview conducted with the Regional Delegate for MINTOUR in the South West Region, Mr. Elangwe Peter Pel (April, 2015), the researcher was told that “... the lack of funds for the running of the DDMINTOUR in KMD is the paramount reason for the none existence of this office in KMD but 'Since the state machinery runs slowly but surely', this office will soon be created, and it is just a matter of time...".

The absence of this delegation is a major setback to the proper functioning of ecotourism and its related activities within the division. Hence, it was even difficult to have concrete statistics on the field concerning the number of tourists that visit the division over the past years (especially in Nguti and Tombel) but for that obtained from the Bangem Council. It was also noted during field survey that the few hotels and inns in Nguti, Tombel and Bangem Sub-divisions do not keep records for their visitors and the reason for this was negligence and insincerity.

\subsection{Forest Resource Degradation}

Forest resource degradation is also another challenge of ecotourism development in KMD. Poverty remains a major drive behind unsustainable hunting and the bush meat trade. The people of this area face the problem of limited survival options (other than hunting and selling of bush meat) to meet up livelihood imperatives. Hence, they engage in illegal hunting and sometimes they are caught and their meat seized (Plate 5) and auctioned to the general public still by the very authorities who caught them. 


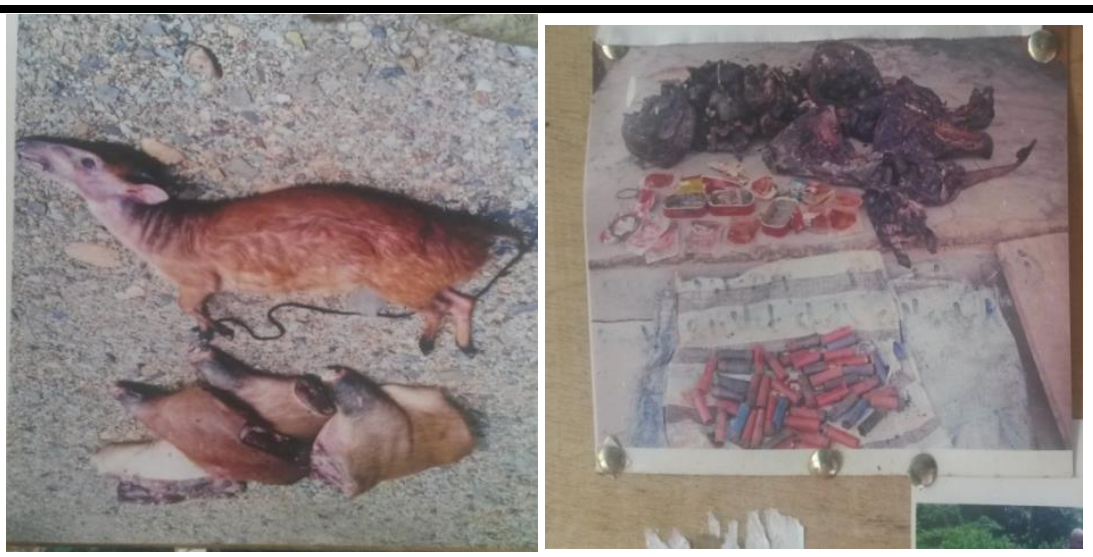

Plate.5: Killed Animals in the BMWS

Source: Photographs courtesy BMWS Office, August, 2015

In Manyemen Town in Nguti Sub-division for instance, there is a market for the sale of bush meat with the prices ranging from 5,000FRS CFA (for a piece of meat weighing $2 \mathrm{Kg}$ ) to about $12,000 \mathrm{FRS}$ CFA (for a piece of meat weighing $5 \mathrm{Kg}$ ), and it is common to see all the local restaurants in the division selling their food stuff with bush meat. Meanwhile, some unscrupulous hunters are specialized in killing elephants for ivory tusk. Hence, the protected areas in KMD (BMWS, BNP, and MKF) that are a honey spot for ecotourists are undergoing constant threat through unsustainable hunting and deforestation. It should be noted that these protected areas are endowed with endangered species and some of them are even endemic only to this division. Examples of some of these endangered and endemic species of fauna and flora include: elephants, hipopothemus, the Mount Kupe Bush Shrike, Prunus africana and hard tropical iron wood ('Azobe') just to mention a few.

Deforestation too is another major challenge. The cutting down of trees be it for timber exploitation (like the WIJMA Timber Sawmill company in Nguti), agriculture, road construction, settlement or the massive deforestation of hundreds of hectares of land by the large industrial

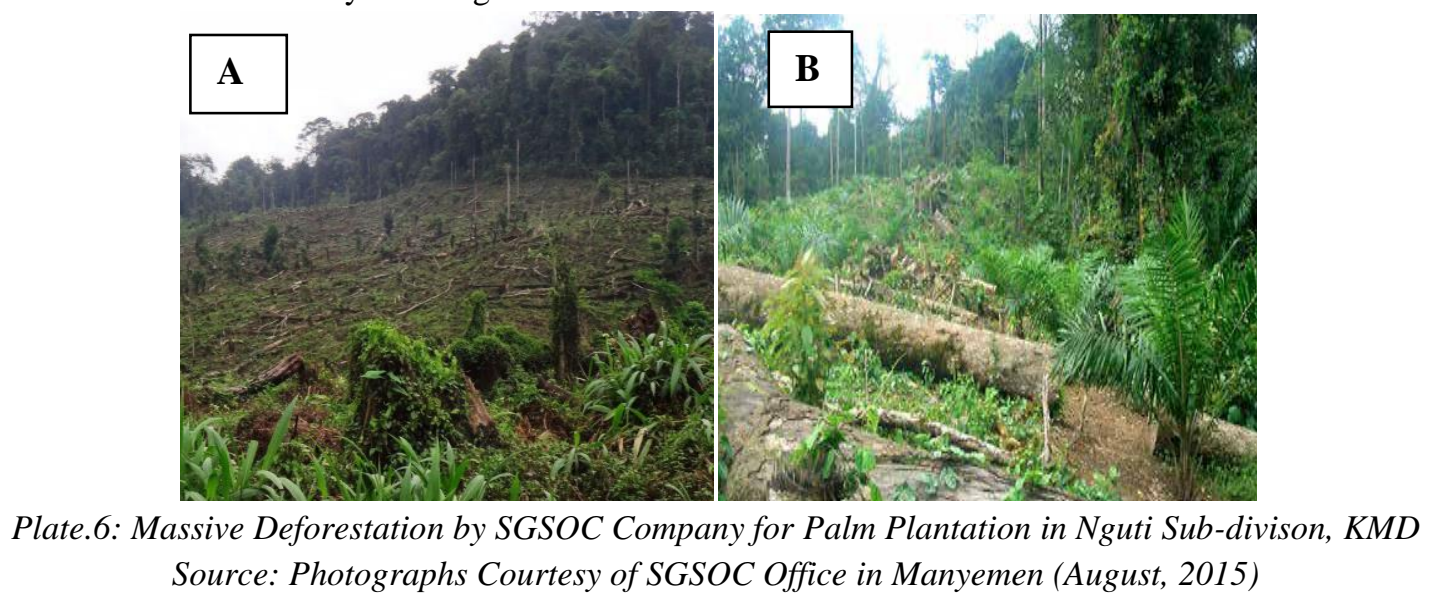

Plate.6: Massive Deforestation by SGSOC Company for Palm Plantation in Nguti Sub-divison, KMD Source: Photographs Courtesy of SGSOC Office in Manyemen (August, 2015)
Complex- Sithe Global Sustainable Oils Limited (SG SOC), as illustrated on Plate $6 \mathrm{~A}$ and B. According to Fonjong et al. (2015) and Achobang et al. (2014), SGSOC was to occupy about 73,000 hectares of land in Kupe Muanenguba and Ndian Divisions in the South West Region of Cameroon for agro industrial plantations, but Achobang et al. (2014) hold that about 42,000 hectares of forest in KMD precisely in Nguti Sub-division was to be deforested by the company for their oil palm plantation. But the Presidential Decree No. 2013/416 of $25^{\text {th }}$ November 2013 attributed only 13,195 hectares of land to SGSOC in KMD and in Ndian Division. Whatever the case, if the SGSOC Company finally deforests 42,000 hectares of land in KMD for oil palm plantation as postulated by Achobang et al. (2014), this will obviously go a long way to destroy hundreds and even thousands of plant species in which some are of medicinal values and others are used for food like the NTFPs. Apart from this, the animals and birds that live in the deforested area will be deprived of their natural habitat. These acts of poaching and deforestation have greatly affected ecotourism potentials in KMD. 
Related to poaching and illegal hunting is the degradation of Mount Kupe Forest (MKF). The MKF and its resources have been subjected to severe degradation due to a variety of human interventions. In this forest for example, environmental degradation is as a result of poor agricultural practices, intense bush burning, over grazing and over exploitation of NTFP, deforestation and unsustainable hunting of wildlife resources. Lumbering of some timber species like 'iroko', 'isapelle' and 'pebbe' wood which are needed by fauna for nesting and feeding especially in these forest in KMD (like the MKF and the MMF), are a disturbance for these animals and birds. These activities jeopardize the future generation and their right to have access to and enjoy the use of a healthy environment and the resources it contains.

\subsection{The Difficult Nature of the Terrain}

Kupe Muanenguba Division is a division that is characterized by a very difficult terrain, made up of hills and valleys. This makes movement by foot difficult and anyone venturing to this division for tourism or other purposes must be determined to reach his/her destination because of the difficult nature of the terrain. Moving into the Mbo hinterland for example, one encounters steep hills and deep valleys in a forested environment characterized by mosquitoes and other insects. Going to the Bermin Lake either from Bangem or from Nguti is not easy because of the nature of the terrain. This is further worsened by the poor nature of the road in which in certain places, it becomes even difficult for a bike to pass through. This is aggravated by the soft nature of the soil that often make the roads muddy and slippery. On the Muanenguba caldera, clouds always cover this caldera in the early hours of the morning and towards the evening thereby reducing visibility during these periods.

\section{CONCLUSION}

By and large, ecotourism is a recreation and leisure time activity that is gradually gaining grounds in KMD. The rich and varied topography, floral and faunal biodiversity as well as multi-linguistic and cultural diversity of this division provide the primary components necessary in making KMD a very fertile terrain capable of attracting ecotourists and promoting ecotourism activities as a whole. Culturally, the people of KMD have a diversity of cultural heritage ranging from the uniqueness of their traditional houses, traditional manifestations, and cultural artifacts just to name but these.

For tourism/ecotourism to effectively take place in any destination, the role of accommodation is very important to boost this activity. Unfortunately, the standards of accommodation facilities like hotels and guest houses in KMD are still mediocre, owing to the fact that services in these hotels such as the restaurant service, water system in the toilets and internet service need to be ungraded to meet national and international standards.

The challenges of ecotourism development in KMD range from poor road network, poor accommodation, poor state of the restaurants and language problems amongst others. If all these challenges are overcome and the suggested recommendations implemented by all the stakeholders in the ecotourism domain, then, there will be wonderful prospects for the development of ecotourism in KMD in the nearest future.

\section{RECOMMENDATIONS}

Though a myriad of challenges exist in KMD that have slowed down the development of ecotourism in the area, a number of recommendations are hereby postulated that if properly implemented can act as a panacea for these challenges. These recommendations are addressed to:

\subsection{The Cameroon Government (Public Sector)}

$>$ The government should constantly maintain the roads and if possible tar the roads, so as to boost tourism activities as well as other economic activities within the division. The maintenance of roads is a necessary tool for investment in the light of economic emergence. The huge potentials that KMD is endowed with if harnessed, will lead to economic diversification and boost other economic activities.

$>$ The divisional delegation of MINTOUR be created in KMD and personnel appointed to make it functional. If this is done, this office will act as a central coordination unit for all other stake holders involved in tourism and nature conservation endeavors and this will go a long way to promote ecotourism development in KMD.

\subsection{The Local Councils}

> The councils in the division should include in their organigram a service in charge of tourism development. This service will be in charge of identifying all the tourism potentials in the municipality, coordinate all the tourism related issues like assisting tourists (by acting as tourists guides) and also propose strategies for the development of the tourism potentials within their municipality. This service should work hand in glove with the DDMINTOUR in order to foster ecotourism development in their respective council areas. In short, a good institutional framework of tourism development in each council be set up to facilitate tourism development in these councils.

$>$ The three councils of the division should seek for aid from international donors/organizations that are interested in nature conservation. These councils could also initiate fund raising networking or 
partnership with other councils in Europe that will assist them with the necessary finances to boost tourism development in their respective council area. They could as well work in synergy with these foreign bodies for their human resources to be trained so as to better manage their forest and wildlife resources.

\subsection{The Population (Private Sector)}

$>$ The population of KMD should always collaborate with the government, NGOs and other stakeholders of the tourism sector to make sustainable use of their forest and the wildlife resources. Meanwhile, private investors in the tourism sector should create souvenir shops and stock these shops with valuable items that reflect the natural environment of KMD and Cameroon as a whole. When items in these shops are bought, they will continue to act as a reminder of Cameroon to the tourists each time they glance at the item(s) bought from the shops.

$>$ The population should judiciously hold their tradition and cultural heritage very close to their hearts and endeavor that it should not be contaminated by modernism.

\subsection{The Ecotourists intending to visit KMD}

$>$ Tourists intending to visit KMD should endeavor to visit the local council offices where souvenir items will be bought and taken home to their respective countries. At the council offices, they will be given lectures on the ecotourism potentials that the council area is endowed with and an eco-tour guard to take them around the municipality to the various tourism sites.

\section{REFERENCES}

[1] Annuaire Statistique du Cameroun, 2000.

[2] Annuaire Statistique du Cameroun, 2010.

[3] Achobang, F. C., Nguiffo, S., \& Schwartz, B. (2014). SG sustainable oils Cameroon PLC (SGSOC), Conflict or consent? Oil palm sector at cross roads pgs 335-360.

[4] Ayonghe, S., \& Titanji, V. P. K. (2001). Lake Nyos and other explosive volcanic lakes in Cameroon: facts, media coverage and myth. In J. Dunlop \& W. Roy (Eds.), Culture and environment. University of Stratchclyde, Glasgow.

[5] Benneth, G. (Ed.). (2008). Cameroon; Encyclopedia Britannica.

[6] BMWS (2013). Quarterly report of Banyang Mbo Wildlife Sanctuary of 2013.

[7] Check, M., Pollard, B. Derbyshire, I. Onana, J.M., \& Wild, C. (2004). The plants of mount Kupe, Muanenguba and Bakossi mountains, Cameroon; A conservation Checklist, London, Kew Publishing.
[8] Chombeng, R., G. (2015). Cameroon: A Geographical Account, Limbe-Cameroon. Vision Educational Publications,

[9] Diabe, S. (2010). Problematic of the construction of a Bororo territory in the Muanenguba Caldera, An Unpublished M.Sc. Thesis, Department of Geography, University of Dschang.

[10]Ejedepang, K. (1986). A Tradition of the Bakossi people, Alexandra Virgina.

[11] Falade, G. O. (2000). Understanding tourism in Nigeria. JIS Printing.

[12]Fonjong, L., Sama-Lang, I., Fombe, L., \& Abonge, C. (2015). Disenchanting voices from within: interrogating women resistance to large-scale agroinvestment in Cameroon, 2015. World Bank Conference on Land and Poverty, World Bank Washington DC.

[13]Fotso, E. \& Ewane, N. (2001), An ecological study of Mount Muanenguba, USA, Pitts Publishers.

[14]Honey, M. (2008). Ecotourism and sustainable development, who owns paradise ( $2^{\text {nd }}$ Edition). Washington DC: Island Press. http:/Whc.Unesco.Org/En

[15] IUCN (2007). Conservation on biological diversity, available on https/www.cbd.int/gender/doc/fs_uicn_biosafety.pdf accessed august, 2015

[16]Lambi, C. M. (2010). The environment and development frontier in Sub Saharan Africa: some global lessons. Bamenda: NAB Ventures.

[17]Melle, I. (2009). 'Ecos' of the Twin Lakes, ecotourism development in Mwaam (Muanenguba) Cameroon. Department of Business and Service Management, London Metropolitan University.

[18] Mesmin, T., \& Fogwe, Z. N., (2009). Ecotourism in protected areas of Cameroon; trends, problems and prospects. In C. M. Lambi (Ed.), Cameroon: a country at crises crossroads (197-221). Bamenda; Cameroon: NAB Ventures.

[19] Mesumbe, I., N. (2001). The ecology of Mount Kupe Forest, a Master Thesis, Department of Geography, University of Buea.

[20] Ministry of Tourism (MINTOUR) (2012). Ninth meeting of the national tourism board final press release, Yaoundé, MINTOUR.

[21] Ndenecho, E. N. (2005). Biological resource exploitation in Cameroon, from crisis to sustainable management. Bamenda: Unique Printers.

[22] Ndenecho, E. N., \& Fonteh, M. L. (2012). Freshwater and Coastal Resource Management in Cameroon, Building Resistance and Resilience to Climate Change. Bamenda: AGWECAMS Printers. 
[23] Ndenecho, E., N. (2011). Local livelihoods and protected area management, biodiversity conservation problems in Cameroon, Langoa PPCIG Mankon, Bamenda.

[24] Neba, A. S. (1987). Modern Geography of the Republic of Cameroon ( $2^{\text {nd }}$ Edition). Bamenda; Cameroon: Neba Publishers.

[25] www.birdlife international.org 